\title{
ENTRE ENIGMAS TEXTUAIS \& ESFINGES VISUAIS: O Mito de Édipo na narrativa pictórica de Gustave Moreau Enéias Farias Tavares'
}

"Eu preciso confessar que, diante de um trabalho como esse, eu mais desconfio do que confio em mim mesmo." Gustave Moreau, sobre Édipo e a Esfinge.

"A esfinge era o problema mais grave na lógica da narrativa, um problema que os poetas nunca resolveram." Carl Robert, Oidipus.

RESUMO: Na obra de Gustave Moreau (1826-1898), pintor parisiense associado ao movimento simbolista, há uma multiplicação de monstros femininos que serão contrapostos a heróis masculinos feridos, decapitados ou alquebrados. Neste ensaio, estudaremos a interpretação do pintor ao tema de Édipo e a Esfinge. Nela, Moreau produzirá uma narrativa visual, constituída de várias pinturas, a fim de comunicar o que via de desafiador neste mito, além de produzir uma releitura que nos permite compreender a extensão do problema cultural e psicológico presente na recuperação deste mito na modernidade.

PALAVRAS-CHAVE: Artes comparadas; Literatura; Pintura; Gustave Moreau, Esfinge.

1 Professor adjunto do Departamento de Letras Clássicas e Linguística, da Universidade Federal de Santa Maria, em 2014, publicou A lição de anatomia do temível dr. Louison, romance ganhador do Prêmio Fantasy, da Casa da Palavra/LeYa. 


\title{
BETWEEN TEXTUAL ENIGMA \& VISUAL SPHINX: THE MYTH OF OEDIPUS IN THE PICTURE NARRATIVE OF GUSTAVE MOREAU
}

\begin{abstract}
In Gustave Moreau's (1826-1898) oeuvre, Parisian painter associated with the symbolist movement, there is a multiplication of female monsters that will be opposed to male heroes who have been injured, decapitated or broken. In this essay, we will study the painter's interpretation of the theme of Oedipus and the Sphinx. In it, Moreau will produce a visual narrative composed of several paintings in order to communicate what he saw as challenging in this myth, as well as producing a rereading that allows us to understand the amount of cultural and psychological difficulties present in the recovery of the myth in modernity.
\end{abstract}

KEYWORDS: Comparative arts; Literature; Painting; Gustave Moreau; Sphinx.

I.

Entre os mitos fundadores da cultura ocidental, a história de Édipo e seus crimes ganha relevo, não apenas por diagnosticar a incapacidade humana diante de forças divinas ou naturais incognoscíveis e incontroláveis, como também pelo estrato psíquico presente na história de um herói cuja principal qualidade não está na força ou na ascendência divina e sim na capacidade intelectiva. Édipo, todavia, é um modelo agridoce e ambíguo, trágico por excelência; aquilo que lhe confere supremacia sobre o mundo circundante é também o que o condena à profunda ignorância a respeito de si próprio, de suas origens e dos crimes que julgava ter abandonado ao fugir de Corinto.

Os gregos, cientes dessas ambiguidades - extrapoladas e intensificadas na tragédia de Sófocles - enfatizaram no percurso do herói o que a antropologia tomou por um natural rito de passagem. Falamos de um embate ocorrido justamente entre o parricídio e o incesto, ou - para colocarmos em termos menos negativos entre a necessidade de se matar o pai antes de se acessar a maturidade sexual. $\mathrm{O}$ encontro com um monstro feminino que oferta enigmas não foi popular apenas entre os gregos, como também cooptou a atenção de poetas, pintores e pensadores nos últimos dois séculos. Nestes, a revisitação ao mito grego ora visa intenções racionalistas ora objetiva a desconstrução destas, sendo fundamental à própria fundação de disciplinas como antropologia e psicanálise. Comprovam isso os textos de Levi-Strauss, Freud e Jung, que buscam no episódio lendário substratos exemplificadores para suas reflexões sobre cultura, sociedade e psicologia (CONNELL, 2013).

Neste sentido, é interessante notarmos como variadas disciplinas e artes buscaram - em um esforço obviamente indutivo - encontrar na história de Édipo e da Esfinge elementos que reforçassem suas diferentes visões de mundo ou mesmo seus impasses 
conceituais e teóricos. Antes disso ainda, no decorrer do século XIX, são dois os movimentos interpretativos que norteiam a recuperação do mito de Édipo e da Esfinge a fim de comunicar ou explicitar o papel do homem em relação ao cosmos.

Em um primeiro momento, percebe-se o eco iluminista - resquícios de um pensamento cujas origens estão nos tomos literários, filosóficos e científicos dos séculos XVII e XVIII - que prevê o homem como um herói racional e perspicaz, capaz de decifrar os enigmas da natureza, como o herói grego fez diante do monstro que assombrava Tebas. Em um segundo estágio, que culmina na cultura finde-siècle europeia, com todos os seus monstros femininos e damas fatais, há uma desconstrução da pretensa certeza racionalista anterior, valorizando no enigma e na criatura que o profere uma metáfora da constante busca por compreensão e sentido em um universo que não necessariamente os encerra ${ }^{2}$.

Em termos pictóricos, exemplificam a primeira dimensão as telas de FrançoisXavier Fabre (Fig. 1) e de Jean-Auguste Dominique Ingres (Fig. 2), produzidas respectivamente em 1806 e 1808 e de título similar, respectivamente, Édipo e a Esfinge e Édipo explica o enigma da Esfinge. Na primeira, a criatura é contraposta ao cenário natural enquanto o herói grego tenta tocá-la/contê-la entre os dedos ameaçadores, em um gesto de aprisionamento senão físico então psíquico. Na segunda tela, Ingres intensifica os elementos dispostos na obra de seu mestre, não apenas delimitando o tamanho e o espaço da Esfinge na tela, como trazendo à luz e à grande porção da imagem um Édipo heroico, luzidio e ciente de que é tanto o autor da pergunta quanto o formulador da resposta ${ }^{3}$.

Em termos textuais, evidenciam mentalidade similar - com propósitos obviamente diversos - as Lições sobre a Filosofia da Religião (1821), de Hegel, e o conto "A Esfinge" (1846), de Edgar Allan Poe. Em seu ensaio, Hegel definirá o mito da Esfinge e sobretudo seu aspecto híbrido como um estágio anterior da cultura humana no qual o homem ainda não se via totalmente dissociado do elemento natural. Assim, Édipo confrontar o monstro, e sobretudo enfrentá-lo intelectualmente em vez de fisicamente, indicaria o avanço cultural de uma mente racional sobre o panorama de crenças supersticiosas que o rodeavam, sobretudo aquelas que viam na natureza elementos de caráter divinos e sobrenaturais.

Similarmente, o conto do escritor norte-americano transpõe para ficção o mesmo pensamento. Nele, dois amigos fogem de uma peste que assola Nova York e refugiam-se no campo. Lá, um deles vê um monstro gigantesco que se aproxima. O segundo amigo o tranquiliza, dizendo que seu susto não passa de ilusão de ótica e que o monstro que parecia tão ameaçador não passaria de um inseto, preso em uma teia de aranha. A moral do conto é: o que era ameaçador a povos antigos,

\footnotetext{
2 Para um detalhamento do imaginário do século XIX no que tange à representação pictórica de monstros femininos, ver Dijkstra, Bram. Idols of Perversity - Fantasies of Feminine Evil in Fin-De-Siècle Culture (1986).

${ }^{3}$ Para análise deste Édipo positivista, ver "O Silêncio da Esfinge e o Enigma de Édipo na tela de Jean-Auguste Ingres" (TAVARES, 2012).
} 
posto que inexplicável, agora poderia ser facilmente analisado, compreendido e catalogado à luz da ciência.

Esses exemplos pictóricos e textuais mapeiam uma pretensa confiança da parte de poetas, pensadores e artistas na capacidade humana de compreender a natureza - e com ela seus mistérios e enigmas, temas costumeiramente associados à feminilidade e à sexualidade - através do luzidio pensamento racional. Entretanto, o século XIX, não apenas por suas guerras e revoluções como também por sua arte mais e mais agressiva e desestabilizadora, viu essa confiança se esgotar e o século das luzes transmutar-se, sobretudo nas décadas que antecederiam o século XX, em uma era de sombras e incertezas.

No campo da literatura e do pensamento, os poemas de Charles Baudelaire, a obra de Oscar Wilde e os contos de amor e morte de Arthur Schnitzler, entre outros que utilizaram o imaginário da Esfinge, colocaram em xeque a confiança na idealização humana, sobretudo masculina. Os poemas de As flores do mal (1857), por exemplo, aludem à criatura grega como metáfora para a arte, a morte e a sexualidade, seja a imaginada ou a comprada nos bordeis. Wilde publicou um conto (1891) e um poema (1894) nos quais a Esfinge é associada diretamente à enigmática sexualidade feminina e seu efeito fantasmático sobre o imaginário masculino dedicado à arte e à morte. Por fim, em seus Contos de amor e morte - narrativas curtas publicadas entre 1887 e 1917 -, Schnitzler recria esfinges em suas heroínas, quase sempre as associando a cenas de sexo e/ou morte. Ou seja, se o pensamento anterior ofertava esfinges femininas aprisionadas e controladas por altissonantes Édipos iluministas, a segunda metade do século XIX postulou outro imaginário, com homens definhando diante de enigmas ainda sem solução.

Exemplifica este último imaginário a arte de Gustave Moreau (1826-1898), pintor parisiense associado ao movimento simbolista e um dos principais expoentes da arte oitocentista francesa. Em suas pinturas, há uma multiplicação de sereias, górgonas, Eurídices, Judites, Salomés e outras tantas personagens femininas que são contrapostas a heróis masculinos feridos, decapitados ou alquebrados. Neste ensaio, iremos nos concentrar em uma série de pinturas que o artista produziu num período de quase três décadas nas quais o tema de Édipo e a Esfinge ganham relevo. Nelas, Moreau produz uma interpretação perspicaz e complexa, em consonância com o que via de problemático na interpretação do tema em seus dias, além de criar uma narrativa visual que nos permite compreender a extensão do problema cultural e psicológico presente na recuperação deste mito na modernidade.

\section{II.}

Gustave Moreau nasceu em 6 de abril de 1826, filho de Louis Moreau, que tinha por sonho criar uma academia francesa para jovens artistas. Estes seriam educados em Letras, Filosofia, Poesia e História, nos mesmos moldes da cena cul- 
tural florentina do século 15 que deu origem a Botticelli e Michelangelo, pintores que formariam o gosto artístico de seu filho. Arquiteto por formação, Louis foi um dos aprendizes de Charles Percier, grande defensor do estilo neoclássico. Já a mãe de Gustave, Pauline, apreciava música clássica e percebeu o gosto de seu filho por desenho, não apenas o retirando da escola - cuja formalidade este detestava como possibilitando sua educação doméstica (MATHIEU, 2005, p. 12).

Em 1841, aos quinze anos, Gustave fez sua primeira viagem à Itália, levando consigo um caderno de desenho onde registrou sua passagem por lugares como Milão, Veneza e Genova. Este primeiro grand tour fortaleceu sua determinação em tornar-se pintor. Ao voltar para casa, mergulhou não apenas no exercício de sua arte como também nos velhos volumes da biblioteca paterna, onde havia preciosidades datadas do século 16, nas quais encontrou os mitos e temas que dominariam sua pintura.

No ano de 1844, deu início à sua educação formal no estúdio de François-Edouard Picot, um pintor de predileção neoclássica, enquanto estudava a arte de Flaxman e Delacroix, a quem seria eterno devedor, sobretudo pela valorização que este deu à pintura histórica em uma época essencialmente realista e paisagística. Esta formação garantiu a Moreau a entrada na prestigiada École de Beaux-Arts, em 1846.

A partir de 1848, começa a expor e a participar dos salões em que os grandes mestres mostravam sua arte. Muitas de suas telas não foram aceites e dentre estas, poucas acabaram sendo vendidas. Ademais, seu gosto pela cor em detrimento da linha, justamente o que o alocava ao lado dos renascentistas que tanto admirava, antagonizava os pintores tradicionais, apreciadores da clareza do traço e dos temas menos heroicos, como atesta a popularidade de Gustave Courbet e JeanFrançois Millet nos mesmos anos. Sobre esta cena cultural, Moreau escreveria ao seu pai: "Eu desejo criar uma arte épica que nada tem a ver com a arte das escolas" (apud LACAMBRE, 1999: 20).

Em 1852, a família Moreau muda-se para a casa de número 14 na Rue de La Rochefoucauld, casa onde Gustave viveria toda a sua vida e que após sua morte daria asilo à grande maioria de suas obras, sediando o museu que leva seu nome. Este ano também marca sua primeira exposição no Salão de Paris. Em 1856, planeja uma temporada de um ano na Itália para completar sua formação. Esse período acabou durando o dobro do tempo, durante o qual estudou Michelangelo, Ticiano e Carpaccio, firmando amizade com Edgar Degas e retornando à Paris em 1859 (MATHIEU, 2005: 15).

No mesmo ano, Moreau conhece e inicia sua relação com Alexandrine Dureux, relação que duraria toda a sua vida apesar de os dois nunca a terem formalizado. Em 1862, após a morte de seu pai, Moreau aceita a encomenda de 14 telas que representem as estações da paixão de Cristo para a igreja de Decazeville, em Aveyron, trabalho que permaneceu anônimo por pedido seu (SERRA, 2013: 12-13).

Nesses primeiros anos da década de 1860, começou a estudar para a composição que o apresentaria ao cenário francês e que permaneceria até hoje como uma 
de suas mais famosas telas: Édipo e a Esfinge, obra que ele expôs no salão de 1864, não apenas lançando sua carreira como também dividindo opiniões.

\begin{abstract}
A tela produziu alvoroço e os críticos correram para discutila logo depois da abertura da exposição: alguns para louvála, outros para criticá-la. Entre estes estavam os campeões do naturalismo para os quais a pintura - decorativa, sensual, refinada - se opunha diretamente. A principal referência contida nela é Ingres e sua pintura de 1808, dedicada ao mesmo tema, na qual a Esfinge é também feminina e meiohumana; mas Moreau fez seu monstro apertar Édipo em um estranho e íntimo abraço, como se lhe sussurrasse algum segredo. (LACAMBRE, 1999: 44, tradução nossa).
\end{abstract}

A relação entre os dois pintores é bem comentada e não raro a obra de Moreau é diretamente contrastada com a tela de Ingres. Mas antes de chegarmos a ela, é preciso voltar um pouco no tempo e compreender não apenas a importância do tema ao próprio artista nos anos anteriores como também uma possível fonte clássica para a sua elaboração. Como veremos, o tema da Esfinge e suas implicações caracterológicas para o herói grego fascinaram Moreau desde sempre. Embora a pintura exposta em 1864 seja o ponto inicial de sua dedicação oficial ao tema, há indícios de que ele começou a trabalhar nela anos antes, com um esboço que se conecta à última pintura que ele dedicaria ao tema ${ }^{4}$.

Neste esboço, um Édipo reticente aproxima-se de uma criatura que o observa impassível, em um estilo que é mais "ativo e dramático" do que o "estático e simbólico" da versão apresentada no salão de 1864 (KAPLAN, 1974: 23). Esse esboço não concluído dá ao todo da narrativa um aspecto cíclico interessante para compreender como Moreau trabalhou com o mito e de que modo sua narrativa pictórica foi construída, não na sequência linear exposta aqui e sim em um emaranhado de esboços e estudos, reflexões e retrocessos, no vai e vem criativo de seu estúdio.

Se Moreau já tinha conhecimento do episódio final que queria comunicar, como veremos doravante, ele optou por retroceder em sua reflexão, por razões que têm a ver tanto com seu conhecimento da arte cerâmica grega como também com a releitura que faria da versão de Ingres. Se estivermos corretos nesta conjectura, deveremos retornar aos anos italianos de Moreau (1857-1859), quando o jovem pintor pode ter estudado não apenas a arte pictórica renascentista como também velhos vasos de cerâmica dedicados ao mesmo tema.

Da arte cerâmica grega, que aumentou grandemente no quinto século em razão do comércio de azeite de oliva no Mediterrâneo e no Egeu, há dois episódios de origem épica de grande repercussão que possivelmente enriqueceram o imaginário popular daquela cultura. Afora as cenas de batalha que serviriam de ótimo

${ }^{4}$ Para o esboço, ver Kaplan (1974: 23 e 82). 
adendo visual a Ilíada homérica e o confronto entre Ulisses e o ciclope Polifemo, cena retirada da Odisseia, o encontro entre Édipo e a Esfinge capturou a mente de pintores e de poetas no período. Porém, se Ésquilo, Sóflocles e Eurípides ressaltaram em suas peças a fase posterior da vida de Édipo, após a trágica concretização de seu destino, os artistas cerâmicos buscaram um tema de maior apelo visual, justamente o embate do herói com o monstro proponente de enigmas ${ }^{5}$.

De um grande número de exemplares sobreviventes e que comunicam diferentes estágios de interpretação e detalhamento do mito, há três exemplos que poderiam ter interessado a Moreau quando visitou os museus e galerias italianas, onde estavam boa parte das peças originais gregas. Em Édipo assassinando a Esfinge (Fig. 3), por exemplo, produzida entre 420 e 400 a.C., temos um herói que confronta fisicamente a criatura. Nesta versão, a Esfinge não passa de uma presa animal, subjugada ao seu atacante humano. Esta imagem parece registrar um momento anterior ao mito no qual não há enigma ou diálogo, apenas um confronto violento e de caráter iniciático, em que um herói precisa combater o monstro para salvar a cidade e ganhar a mão da princesa ou rainha. Segundo Kerényi, originalmente Édipo teria de atacar a Esfinge no "monte Fícion. Assim, um vaso nos mostra Édipo erguendo a maça para golpeá-la, sem refletir sobre nenhum enigma, diante da virgem-leoa" (1998: 87).

Por outro lado, em Édipo decifra o enigma da Esfinge (Fig. 4) temos uma imagem mais reconhecível ao imaginário moderno, talvez coadunada com a visão de Sófocles em seu Édipo Rei (429 a.C.). Nesta, o herói está vestido e posta-se com tranquilidade diante do monstro enigmático. Esta versão é a mais popular, algumas interpretações ressaltando o diálogo, outras o olhar contemplativo de Édipo diante da Esfinge. Uma versão mais conhecida é aquela que apresenta Édipo sentado diante de uma artificial Esfinge, que não apenas é menor como está alocada sobre uma colunata grega, na possível identificação de uma natureza híbrida e estranha, que foi contemplada, decifrada e controlada pelo herói humano.

Todavia, no final do século $\mathrm{V}$, temos uma estranha e singular representação que parece inverter as duas fórmulas visuais anteriores, expressando o contato dos dois personagens com sugestivos traços de intimidade física e psicológica. Em Esfinge seduzindo um jovem (Fig. 5), a criatura dá a volta no herói e lhe abraça, contornando seu corpo nu com suas patas leoninas, penetrando seus olhos com um olhar que é inegavelmente especular. Ainda mais: a silhueta dos dois, herói e monstro, Édipo e Esfinge, é curiosamente semelhante, como se fossem gêmeos imperfeitos, separados por estranhas circunstâncias.

Diante dessa grande variedade de interpretações visuais, Moreau pode ter recusado da cerâmica grega os temas do embate físico e do embate discursivo, duas interpretações que apontavam igualmente para a ambígua superioridade humana diante da criatura. Ao invés dessas, Moreau estabelece por ponto inicial de sua

\footnotetext{
${ }^{5}$ Para um estudo detalhado da arte cerâmica grega em relação à produção poética contempo-
} rânea e seus possíveis pontos de contato, ver Kerényi (1998) e Snodgrass (2004). 
narrativa pictórica o momento singular no qual os anônimos artistas gregos haviam interrompido sua própria reflexão do mito. Quando emparelhadas (Fig. 5 e 6), vemos que Moreau recria em sua tela no mínimo três elementos da fonte grega: a) o contato visual especular entre Édipo e a Esfinge; b) o contato físico sensual entre os dois personagens; e c) contato erótico, ressaltado pela nudez de Édipo, nudez incomum em outras representações cerâmicas e também no modo como o próprio Moreau representaria Édipo em versões posteriores.

Após essa primeira referência, direcionemos agora nosso olhar à versão de Ingres, produzida em 1808 e revista pelo pintor em 1864, ano em que Moreau exporia a sua própria versão. Se Ingres apresentaria Édipo como personagem central, perguntando e respondendo ao enigma, e trataria da Esfinge como uma criatura das sombras, coadjuvante e afugentada pelo poderoso herói, Moreau responderia sistemática e contrariamente a cada um desses pontos em sua própria obra. Em vez da centralidade humana, o pintor daria aos dois personagens um espaço igual em sua tela, dividindo-a em duas porções perfeitamente equilibradas: a da esquerda dedicada à esfinge e a da direita, ao herói. Do monólogo de Ingres, Moreau silenciaria o herói humano, duplicando o contato entre eles ao nível dos corpos e dos olhares. Por fim, da acuada Esfinge da pintura anterior, Moreau cria em sua versão uma criatura atuante e nem um pouco intimidada, tão interessada no herói quanto este nela ${ }^{6}$.

Adamais, Moreau suspende a costumeira vitória associada a Édipo, vitória dada por certa por muitos dos intérpretes do mito, como destaca Connell (2013). Ademais, como Palarilhe e Pierre afirmam,

Ingres, que está possivelmente bem certo da vitória de seu herói, pinta apenas parte do corpo da Esfinge. Já na obra de Moreau, a Esfinge ocupa o centro da pintura e está cravando suas garras no peito de Édipo. Se não soubéssemos da história, teríamos dúvidas sobre a vitória final do herói e, na verdade, Moreau com frequência figurará a Esfinge como vitoriosa e entronada sobre uma montanha de corpos. Há assim, uma grande diferença entre as versões dos dois pintores; a ameaça, reduzida por Ingres ao nível do diálogo pacífico, aparece com grande força na pintura de Moreau. O teste de força agora não é mais medido pela "palavra" do enigma, pela inteligência apenas, como foi colocada por In-

\footnotetext{
${ }^{6}$ A crítica a Ingres exemplifica também a visão que Moreau tinha de sua arte. Em caricatura feita nos anos 1850, Moreau coloca um atarracado e ensimesmado Ingres encontrando um elegante e indiferente Delacroix na frente do Instituto Francês. A forma pouco simpática e nada atraente com que o artista neoclássico é apresentado em contraste com o aspecto esguio e charmoso do pintor romântico pode indicar o modo como Moreau também encarava suas respectivas obras. Ver Lacambre (1999: 23).
} 
gres e pelos gregos, mas pela comunicação física deste desafio na imagem do homem e do monstro (1971: 95).

Os autores aqui sugerem que o ponto de contraste entre as duas versões estaria entre uma vitória certa na tela de Ingres e uma desconfortável dúvida quanto à conclusão do embate na versão de Moreau. Mais que isso, estamos acessando nesta segunda tela uma ambiguidade que é tanto intelectiva quanto física. Intelectiva porque os olhares do herói e do monstro denunciam imersão na imagem alheia, podendo esta devolver uma significação impossível de se obter nos seguros reinos da solidão anterior dos dois personagens, ambos indecifrados até ali - ambos talvez indecifráveis também depois deste encontro. Mas este, além de intelectivo é também físico, denunciando menos a violência presente nas versões primitivas do mito e mais o contato fantasmático que compreende afeto, erotismo e sexualidade.

O problema dado por resolvido por muitos leitores do mito e enfatizado por Ingres na criação de seu Édipo iluminista agora dá lugar a um problema fulcral da psicologia do herói, um herói que antes de ser decifrador de enigmas é aquele que se torna incapaz de responder a mais simples das perguntas: "Quem sou eu?”. A tragédia de Édipo está justamente em não ter percebido que decifrar o mundo externo e seus enigmas, sejam eles animalescos ou oraculares, não compensa sua ignorância a respeito de quem é, de quem são seus pais e de onde ele se origina. Não coincidentemente, o poeta Théophile Gautier, diante da tela de Moreau, afirmou estar diante de um "hamletiano Édipo" (apud FOREST, 2009: 11).

Kaplan sugere que Moreau pode ter estado inicialmente interessado em expressar os conflitos antagônicos das "forças da vida e da morte, do princípio masculino e do feminino, do bem e do mal" ou mesmo o conflito entre "o idealismo moral e o desejo sexual" (1975: 22), como Moreau faria em diversas de suas obras de temática mítica. Todavia, por mais que interpretações alegóricas e dualistas sejam possíveis, suspeitamos que o artista parisiense, como tantos contemporâneos e conterrâneos seus que se dedicaram ao mesmo tema, quer em palavras quer em cores, tenha ido mais longe em sua reflexão.

O próprio Moreau nos deixou um testemunho de sua relação conflitante com o que estava acessando ao lidar com este mito. Na citação usada como epígrafe deste ensaio, ele revela sua insegurança quanto ao tema grego e seus ecos simbólicos e psicológicos (PALADILHE; PIERRE, 1972: 23). O próprio Moreau escreveu sobre este problema em sua pintura nos seguintes termos:

Na hora mais misteriosa e severa da nossa vida, o homem, o viajante, encontra o eterno enigma, que o pressiona e o fere. Mas sua alma poderosa e forte desafia o ataque brutal e intoxicante da carne; com o olho fixo em sua meta, ele a subjuga abaixo de seus pés e marcha confiante em 
direção ao seu objetivo (apud LACAMBRE, 1999: 45, tradução e grifo nossos).

A passagem interessa por duas razões. Primeiro, pela compreensão do significado complexo do mito e de sua eterna relevância enquanto enigma. Segundo, por também denunciar uma dúbia confiança na capacidade humana em transcender o mistério e a carne. Ora, se Moreau registrou isso com pena, não foi o que executou com seu pincel. Ao contrário, em vez de uma rápida compreensão dualista do que o mito poderia significar, optou justamente pela via mais desafiadora, aquela que o levaria não apenas a desconfiar das visões racionalistas e aparentemente certas sobre Édipo e a Esfinge - visões ilustradas na tela de Ingres - como também a se aventurar pelo mistério que o mito lhe ofertava.

Os passos existenciais e estéticos, senão geográficos, desta jornada foram registrados pelo artista em três pinturas produzidas nas duas décadas seguintes. Tais pinturas, em lugar de relerem a mesma pintura - como Ingres fizera nas diferentes versões produzidas para a mesma tela em 1808, 1826 e 1864 - registram a busca de Moreau por diferentes parâmetros interpretativos. É como se nelas o artista checasse possibilidades, instaurasse tentativas de confrontar o mito e também suas próprias inquietações sobre o tema. Para tanto, produziria em imagem o que poetas, pensadores e filósofos produziram em texto, em uma série de pinturas que, quando contrastadas, contam uma determinada narrativa. Mas aqui, obviamente, não se trata de uma história linear e, sim, uma de possibilidades existenciais que apontam não exatamente para o mito de Édipo e a Esfinge. Antes, objetivam seu possível significado universal, aquele que articula o percurso humano diante dos mistérios do desejo, da sexualidade e da morte.

\section{III.}

No segundo estágio de sua narrativa pictórica - talvez a interpretação mais explícita da violência apenas sugerida por Ingres em sua tela -, produzida dez anos depois de Édipo e a Esfinge, Moreau constrói uma imagem revestida de ironia e agressividade. Nesta nova versão (Fig. 7), finalizada em 1874, temos um Édipo vestido, protegido das intempéries naturais e recoberto dos símbolos régios de poder e soberania, que, sob uma colunata negra, lança a Esfinge em direção a um despenhadeiro após aplicar nela um golpe com sua perna esquerda. Abaixo do herói, corpos masculinos dissolvidos podem aludir ao poder anterior do monstro ou à pretensa soberania civilizatória humana - não coincidentemente também construída sobre os corpos de inimigos vencidos ou de escravos explorados.

Este Édipo agressivo, lançando a Esfinge para a morte, remete visualmente a um estágio primitivo que precede os trágicos e seu verniz intelectivo e dialógico do mito, mesmo que enigmático e não carente de ambivalências. Nesta tela, Édipo é 
um herói físico, um aventureiro hercúleo, um vingador corporal que não precisa de sua inteligência uma vez que sua força e habilidade corpóreas garantem sua superioridade diante do monstro. Por outro lado, Moreau pode também explorar nesta imagem a ilusão civilizatória - bem ao gosto iluminista - segundo o qual o homem domina a selvageria natural, imaginário comunicado por Hegel em sua interpretação do mito e pelas telas de Fabres e Ingres.

Desta perspectiva, o herói agredir o monstro e expulsá-lo de seu trono construído sobre corpos humanos comunica ao observador o primeiro reflexo do contato humano com o mundo natural, um contato baseado na violência, na agressividade e no repúdio. Indefesa, nesta versão do mito a Esfinge não se mata, mas é lançada ao despenhadeiro. Como Connnell afirma, o suicídio da Esfinge não é destituído de ironia - sobretudo se emparelhado a outras mulheres da família de Édipo que também se lançarão ao suicídio, Jocasta e Antígona. Ora, se no mito trágico não é a Esfinge que se mata, então não é Édipo que a vence e sim ela que decide findar com sua existência (2013: 58), com todas as implicações disso.

Nesta perspectiva, Moreau ilustraria na tela a agressividade literal do herói sobre a Esfinge ou do homem sobre a natureza. Ou ainda, a ilusão de vitória do herói e de seus intérpretes quanto à tão noticiada vitória contra o monstro que assolava as sete portas de Tebas. Se optou pela segunda ideia, a pintura de Moreau torna-se ainda mais interessante, pois diagnostica em termos pictóricos o equívoco interpretativo que o mito encerraria e produziria pelos séculos afora. Tal equívoco seria desvelado em sua próxima versão do tema, uma versão na qual o herói vitorioso desapareceria.

Em A Esfinge (Fig. 8), de 1886, o pintor centra sua atenção na própria criatura. O protagonismo da Esfinge nesta e em outras pinturas similares de Moreau comunica sua resistência, quando não sua resiliência, ao esforço humano anterior em vencê-la, quer em termos físicos, quer em termos intelectivos. Indiferente dos esforços edipianos de decifração ou dominação ou empenhos modernos de conceituação e domesticação da paisagem natural, a Esfinge, como símbolo do mundo natural, resistiria.

Se nas outras versões analisadas, Moreau obscurece a paisagem, colocando os dois personagens sobre um cenário petrificado e escuro, nesta a Esfinge é alocada sobre um céu claro e azulado, o que dá à figuração sugestões de delicadeza, leveza e tranquilidade. Em contraste com a porção superior, porém, Moreau apresenta a Esfinge como parte integrante da matéria orgânica, natural e pétrea, fundindo-a ao todo ctônico, fechado e escuro, constituído de pedras, raízes e corpos masculinos mesclados na porção inferior do quadro. Sobre eles, a criatura prevalece, triunfante, a despeito dos esforços de decifração/dominação dos heróis que a confrontaram, ontem ou hoje.

Dijkstra interpreta essas criaturas "virtualmente mescladas a rochas, parte integrantes do cenário natural”, dando como exemplo sereias e esfinges, "como matéria orgânica em decomposição, um empecilho ao ideal masculino em sua busca por transcendência" (1986: 263, tradução nossa). Embora o autor interprete a tela 
de Moreau com chave negativa, como "voraz apetite por chacina humana" (DIJKSTRA: 328), é importante ao menos cogitar direção oposta. Inserida na narrativa visual de Moreau, a tela comunica o contraste entre a visão humana - representada na tela anterior - e o cosmos natural, ilustrado nesta versão. Se a primeira mostrava a violência humana contra o cenário material e terrestre violência explicitada pelo confronto físico - esta versão sugeriria a contrarresposta natural, simbolizada pela vitória da Esfinge e seus enigmas, sejam eles o da corporeidade, da sexualidade ou mesmo o da não transcendência.

Se até então Moreau produziu um tríptico que cerceia a progressão narrativa no primeiro momento de sedução e diálogo especular (Fig. 6), para produzir uma encruzilhada visual que nos leva, de um lado, à violência humana diante da natureza (Fig. 7), e, de outro, à réplica desta à ilusão civilizatória humana (Fig. 8), a obra que encerra o embate conflituoso e dualista seria produzida dois anos mais tarde. Nela, Moreau parece sugerir uma solução ao conflito antagônico que perpassou a essência do mito na forma de uma pergunta: Por que um embate onde poderia haver um diálogo? (CONNELL, 2013: 70). Além disso, pode também oferecer uma alternativa à interpretação ocidental típica, que sempre coloca Édipo como vitorioso decifrador de enigmas e libertador de Tebas, numa "vitória" que, como destacamos, o leva à sua própria desgraça e à desgraça de seus familiares.

Em Édipo o viajante - também nomeada de $A$ igualdade perante a morte (Fig. 9), tela concluída em 1888, Moreau apresenta a conclusão de sua narrativa visual, agora chegando a um possível tema conciliatório para o conflito entre o herói e a criatura. Aqui a ênfase é primeiramente dada a Esfinge, que ocupa a porção central do quadro. Ela está colocada na mesma posição mostrada na tela de dois anos antes, sobre uma montanha de corpos humanos. Mas agora, diferente do embate entre Édipo e ela, e da simples soberania do monstro sobre o orgulho humano, temos um herói claramente modificado.

Agora, trata-se de um "viajante", expressão similar àquela usada por Moreau quando escreveu sobre o "eterno enigma" que encontra o "homem, o eterno viajante”, em sua hora mais desafiadora. O herói é agora um viandante do mundo e de suas várias encruzilhadas, um herói que se aproxima da Esfinge não mais com golpes certeiros ou respostas aparentemente precisas. Antes, o que ele faz nesta nova versão é humildemente reconhecer a importância da poderosa e frágil criatura. Este Édipo não está concentrado nos corpos recém-assassinados ou nas ossadas ressequidas que jazem aos seus próprios pés, testemunhando um conflito de séculos, senão de milênios. Ao contrário, sua postura é cautelosa e humilde. Diante desta, cabe à criatura fatal e enigmática o olhar de surpresa e consternação.

Sobre o processo histórico de silenciamento feminino, mapeado tragicamente no silenciamento da Esfinge e sua relação no mito de Édipo, Jane Connell enfatiza a dificuldade de tratar deste tema, sobretudo pelo viés altissonante dado à vitória do herói no contexto moderno. A autora reflete também sobre o que o mito do monstro tebano comunica à nossa contemporaneidade. Diante de um nítido ato de 
falha ou denegação daquilo que tinha tudo para figurar como diálogo entre o herói masculino e sua nêmese feminina, entre contrapartes que a cultura ocidental afastou, Connell afirma:

Como o sangrento rito de iniciação foi traduzido em um encontro de angústia existencial, inexistia qualquer necessidade estrutural de o sujeito feminino não ser equivalente. Sófocles, em Édipo em Colono, reabilita Édipo após seu fracassado rito de passagem, dando-o outra chance: Mas por que não dar outra chance a ela? Se a Esfinge tivesse mais uma vez uma chance dela, evitando então a posição de vítima, isso lhe colocaria numa posição de maior responsabilidade, diminuindo um pouco a de Édipo. Neste caso, outras possibilidades poderiam ainda ser exploradas. Se ela e Édipo levassem adiante o seu diálogo, este poderia não ter superado a aporia entre os participantes, mas teria evidenciado a "universalidade" da importância de uma crise existencial. O fracasso diante do enigma demonstra a denegação generalizada diante da necessidade de uma crise como essa à maturidade masculina, feminina ou a de qualquer sujeito auto-reflexivo "diferente". (2013: 70).

Nesse sentido, o que estaria em jogo neste mito é justamente o desafio da alteridade, seja esse outro a natureza ou o feminino. Moreau, com sua obra pictórica e narrativa, dispensa as respostas mais comuns e simples, senão simplistas, que resumem o outro - ou a outra - a um monstro que precisa ser dominado, quer pela violência física quer pela violência discursiva. Connell articula que Édipo teria errado o ponto ao responder ao enigma com um "o homem" e não com "a mulher", única criatura que de fato não alteraria sua voz no decorrer das várias fases de sua existência, solução narrativo-discursiva que um pintor não tem à sua disposição. A análise de Connell alude à opinião comum que toma a alteração da voz masculina na adolescência como certa.

Em vista disso, o que Moreau faz - ao revisitar cada opção visual para o mito, como se nos ofertasse uma encruzilhada de diferentes caminhos pictóricos - é levar as possibilidades até seus limites cabíveis. Diante de um abraço/ataque que resulta numa imersão ocular e especular, o que restaria a seguir senão a vitória de um lado sobre outro? A cultura insistiu em produzir leituras e imagens de um Édipo vitorioso, enquanto a natureza continua nos mostrando, ano após ano, década após década, que suas Esfinges tectônicas ou genéticas persistem como guardiãs finais e triunfantes da vida e da morte.

Em sua tela de 1888, o que Moreau articula poderia ser interpretado como um equilibrado encontro dialógico no qual as duas partes envolvidas podem 
reconhecer suas diferenças e refletir sobre suas fragilidades, podendo partir delas em prol de uma possível e pacífica conciliação. Desistindo da resposta e do conflito e aprendendo a respeitar o enigma, talvez fosse isso que o mito comunicaria ainda em sua origem grega ou através das várias Esfinges da narrativa pictórica de Gustave Moreau.

\section{IV.}

O Édipo de Moreau é um herói romântico, vacilante e incerto sobre sua natureza, curiosamente atacado e fascinado pela morte, tanto quanto pelas suas representantes nesta terra: criaturas femininas híbridas, igualmente belas e destrutivas, atraentes e monstruosas. Como Franz Von Stuck faria anos depois - outro pintor fascinado pelo tema e também criador de várias versões pictóricas para o mito -, ao ilustrar o poema de Heine, Buch der Lieder. Como eles, Moreau questiona a vitória de Édipo, invertendo a fórmula e valorizando a Esfinge.

Em sua leitura, o mito não terminaria com a resposta autocentrada de Édipo, resposta que leva ao suicídio da Esfinge e que posiciona o herói no trono do pai assassinado e no leito da mãe conspurcada. Ciente de um mistério que ele não pode compreender ou vencer, bastaria a Édipo baixar a cabeça em sinal de respeito e admiração, cena ilustrada por Moreau em sua tela de 1888 . Ou ainda, fitar os olhos da estranha criatura e receber seu abraço, ambiguamente afetuoso e violento, terno e sangrento, como figurou o pintor francês em sua tela de 1864. Por fim, talvez este enlace terminasse num beijo, como ilustrou Von Stuck em sua tela de 1895 ou como o imaginou Heine no poema de 1827.

Neste caso, o tempo dos violentos embates com o híbrido e inexplicável monstro teria findado. Também os dias das falsas noções, explicações e conceituações no que concerne ao território da natureza ou da feminilidade, confortáveis cadeias conceituais que escondem outros tipos de incerteza, outros tipos de enigmas. Se isso ocorresse, da lembrança de seus efeitos nocivos sobre Esfinges suicidas e Édipos amaldiçoados poderíamos forjar o princípio de um verdadeiro diálogo, entre semelhantes e diferentes, entre corpos e espíritos, entre homens e mulheres, entre heróis viandantes e enigmáticas criaturas encontradas à beira da estrada, nos desconfortáveis pontos cegos de nossas dúbias encruzilhadas. 


\section{REFERÊNCIAS BIBLIOGRÁFICAS}

BAUDELAIRE, Charles. Poesia e prosa. Rio de Janeiro: Editora Nova Aguilar, 2006.

CONNELL, Jane. O silêncio da Esfinge: O erro de Édipo e a redescoberta resposta ao enigma. Fragmentum, Laboratório Corpus: UFSM, v. 2, n. 38, 2013, p.45-71.

DIJKSTRA, Bram. Idols of Perversity - Fantasies of Feminine Evil in Fin-DeSiècle Culture. Oxford: Oxford University Press, 1986.

EDMUNDS, Lowell. The Sphinx in the Oedipus Legend. Königstein: 1981.

FOREST, Marie-Cécile. “Gustave Moreau”. In : BAAN, LASZLO. Terre des mythes - L’Art de Gustave Moreau. Budapest: Musée des Beaux-Arts, 1999.

HEGEL. G.W.F. Vorlesungen über die Philosophie der Religion. Hrsg. Von Walter Jaeschke. Hamburg: Meiner Verlag, 1984.

KAPLAN, Julius. Gustave Moreau. Los Angeles: Los Angeles County Museum of Art, 1974.

KERÉNYI, K. Os heróis gregos. São Paulo: Cultrix, 1998.

LACAMBRE, Geneviève. Gustave Moreau - Magic and Symbols. New York: Abrams, 1999.

MATHIEU, Pierre-Louis. Gustave Moreau - L'Assembleur de rêves. Paris: ACR Edition, 2010.

MATHIEU, Pierre-Louis. Le Musée Gustave Moreau. Paris: Réunion des musées nationaux, 2005.

PALADILHE, Jean. Pierre, José. Gustave Moreau. London: Thames and Hudson, 1972.

POE, Edgar Allan. Histórias de mistério e imaginação. São Paulo: Editora Verbo, sem data.

ROBERT, Carl. Oidipus: Geschichte E. Poetischen Stoffs im Griech. Berlin, 1915.

SCHNITZLER, Arthur. Contos de amor e morte. São Paulo, Cia. das Letras, 1987. 
SERRA, Sophie. Gustave Moreau, le Chemin oublié. Souyri: Editions Au fil du temps, 2013.

SNODGRASS, A. Homero e os artistas. São Paulo: Odysseus, 2004.

TAVARES, Enéias. O Silêncio da Esfinge e o Enigma de Édipo na tela de JeanAuguste Ingres. Todas as Musas, n. 2, ano 3, jan-jun 2012, p. 43-64.. Disponível em: <https://goo.gl/f3bRVk $>$. Acesso em: 10/12/2016.

WILDE, Oscar. Obra completa. Rio de Janeiro: Editora Nova Aguilar, 2003. 


\section{APÊNDICE: IMAGENS E REFERÊNCIAS}
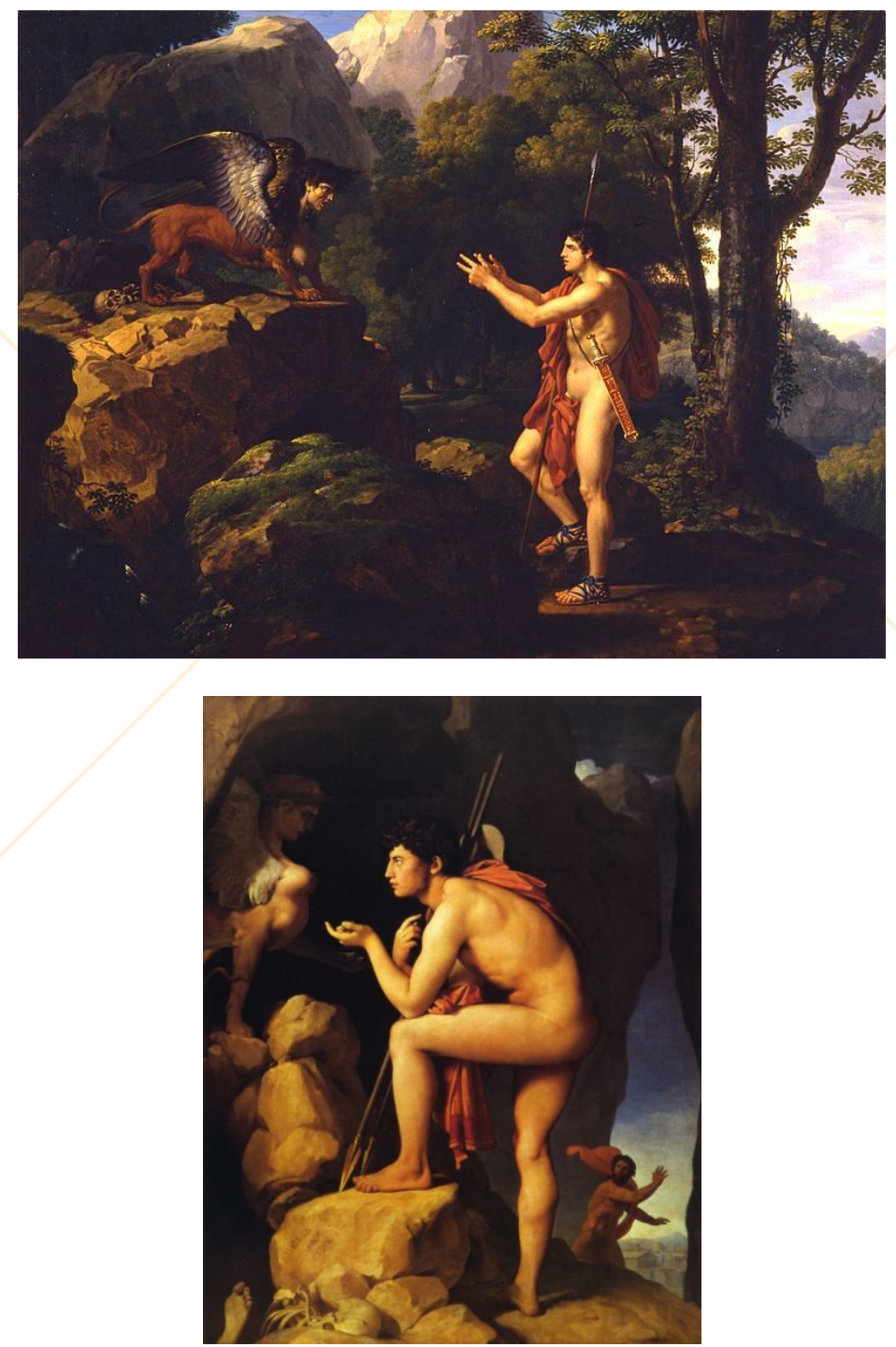

Figura 1. François-Xavier Fabre. EEdipe et le Sphinx [Édipo e a Esfinge]. (1806). Óleo sobre tela, 50 x $66 \mathrm{~cm}$, Dahesh Museum of Art. Disponível em: $<$ https://goo.gl/aO6drT>. Acesso em: 10/12/2016.

Figura 2. Jean Auguste Dominique Ingres. Edipe explique l'énigme du sphinx [Édipo explica o enigma da Esfinge] (1808). Óleo sobre tela, 189 x 144 cm, Louvre. Disponível em: <https://goo.gl/SNDfPw> Acesso em: 10/12/2016. 

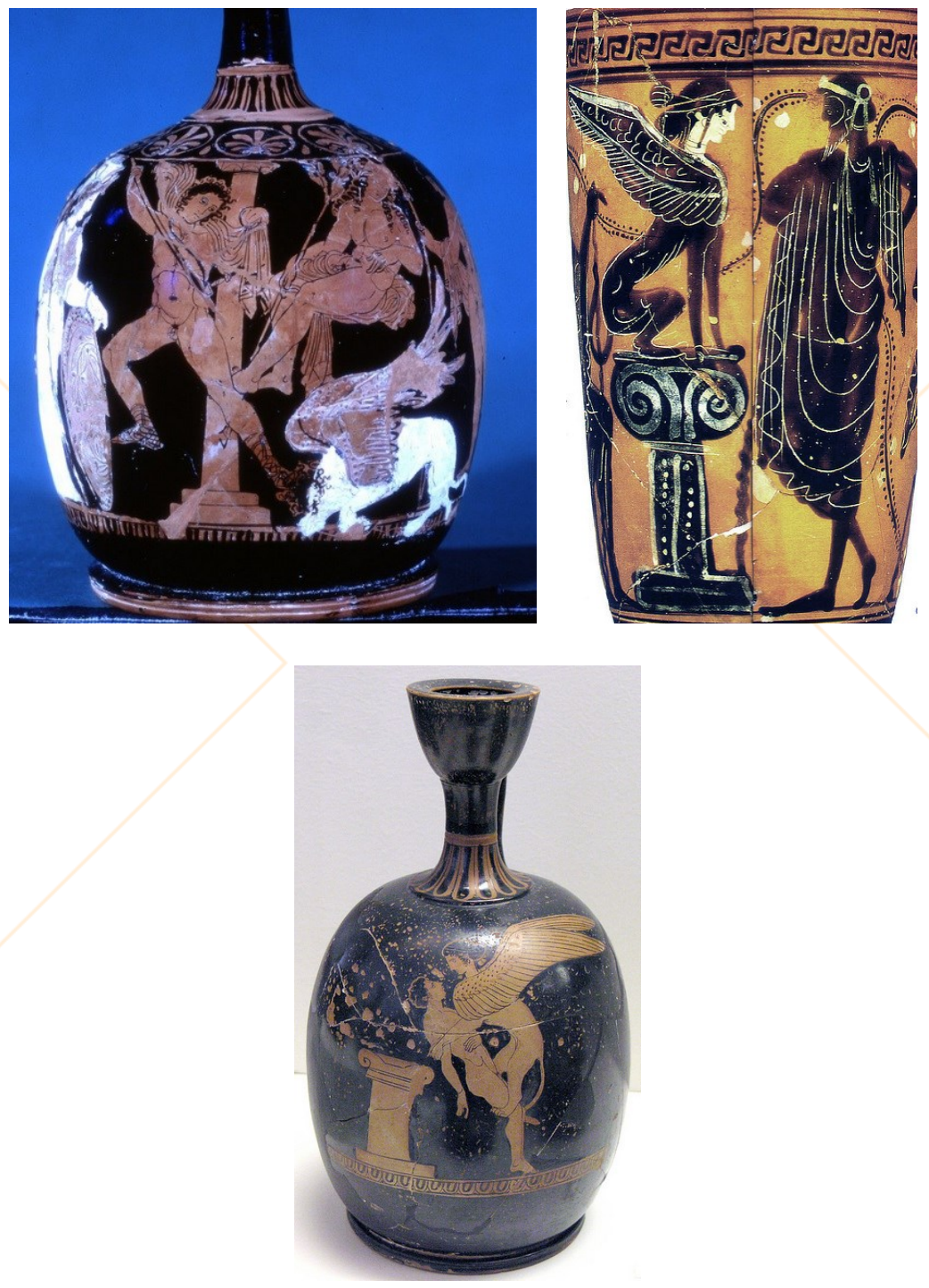

Figura 3. Anônimo. Édipo assassinando a Esfinge (Quinto século a.C.). Cerâmica grega, British Museum. Disponível em: <https://goo.gl/PBQGIl>. Acesso em: 10/12/2016.

Figura 4. Anônimo. Édipo decifra o enigma da Esfinge (Quinto Século a.C). Cerâmica grega, Louvre. Disponível em: <https://goo.gl/MbiheB>. Acesso em: 10/12/2016.

Figura 5. Polion. Esfinge seduzindo um jovem (420 a. C.). Cerâmica grega, National Archeological Museum of Greece. Disponível em: <https://goo.gl/FywrU4>. Acesso em: 10/12/2016. 

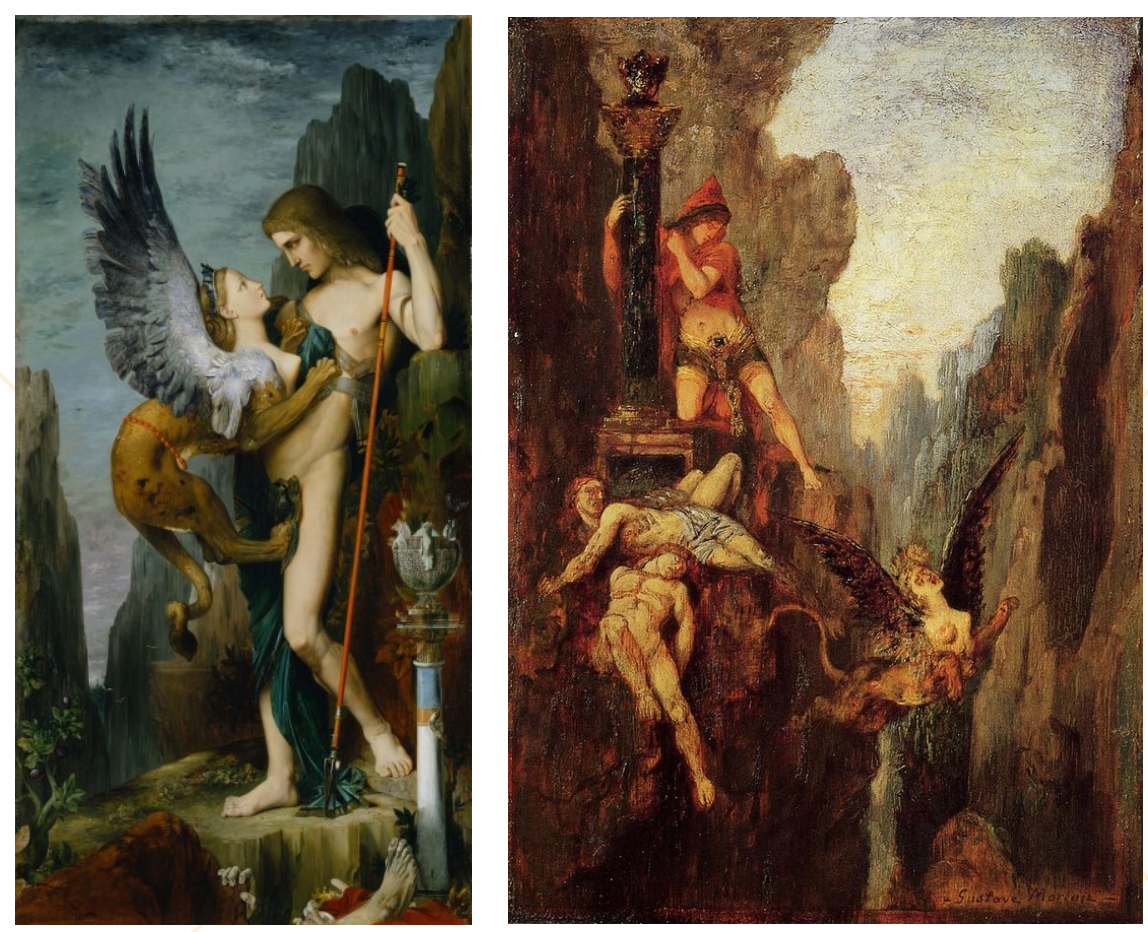

Figura 6. Gustave Moreau. Edipe et le Sphinx [Édipo e a Esfinge] (1864). Óleo sobre tela, 206 x $104 \mathrm{~cm}$, Metropolitan Museum of Art. Disponível em: <https://goo.gl/owt8L3>. Acesso em: 10/12/2016.

Figura 7. Gustave Moreau. Edipe et le Sphinx [Édipo e a Esfinge] (1874). Óleo sobre Tela. 33 x $20 \mathrm{~cm}$, Clemens Sels Museum. Disponível em: <https://goo.gl/f6LyRi>. Acesso em: 10/12/2016. 

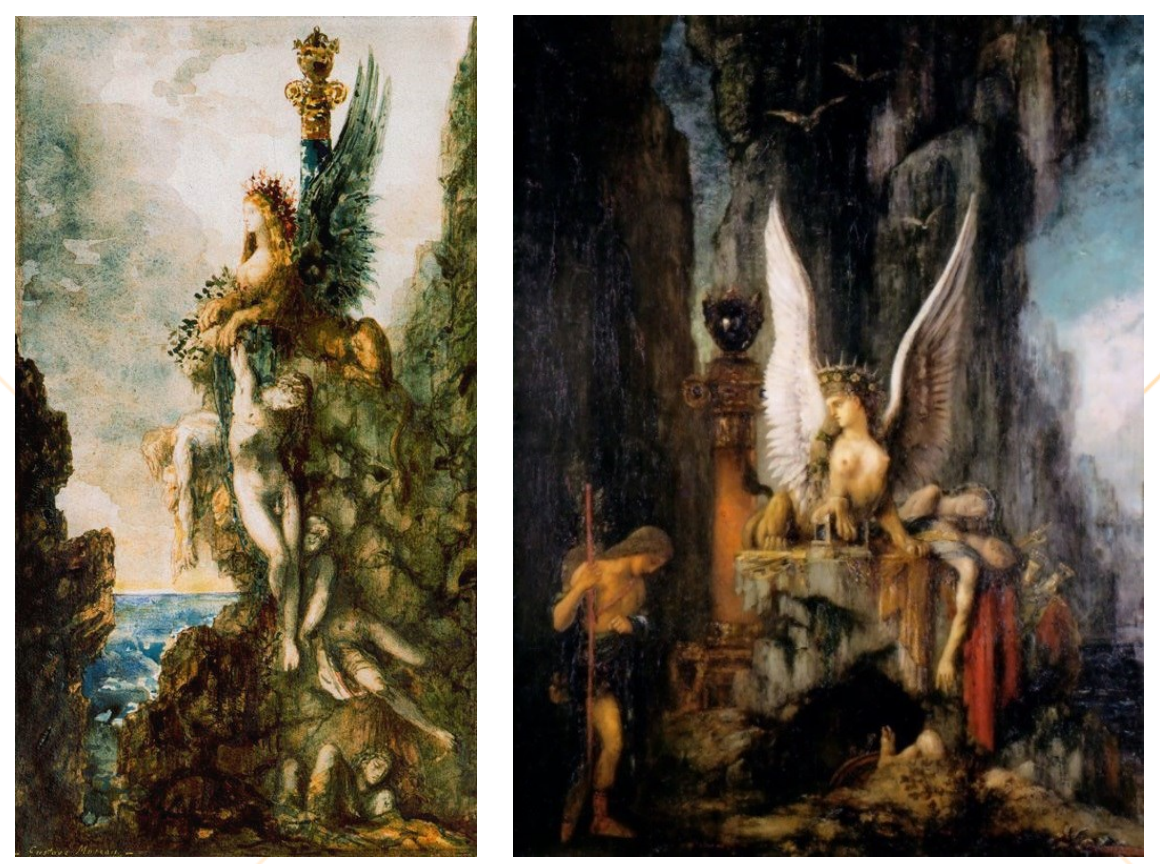

Figura 8. Gustave Moreau. Le Sphinx [A Esfinge] (1886). Óleo sobre tela, 32 x $18 \mathrm{~cm}$, Clemens Sels Museum. Disponível em: <https://goo.gl/7KSfWj>. Acesso em: 10/12/2016.

Figura 9. Gustave Moreau. CEdipe voyageur ou L'Égalité devant la mort [Édipo, o viajante ou A Igualdade diante da morte] (1888). Óleo sobre tela, 125 x $95 \mathrm{~cm}$, Musées de Metz. Disponível em: <https://goo.gl/G9aIpw>. Acesso em: 10/12/2016. 